\title{
Cultural Transformation at Enterprise Level: Case Study Evidence from Poland*
}

\author{
Izabela Robinson, Beata Tomczak-Stepien ${ }^{* *}$
}

This paper presents an analysis of the business cultures of four post-socialist Polish enterprises. Western capitalist orthodoxy emphasises the development and management of an 'appropriate' organisational culture as a key component of organisational effectiveness. Within an East European context it is likewise suggested that the development of appropriate market behaviours is necessary if transforming economies are not to hit a ceiling of recovery. However, what constitutes an 'appropriate' organisational culture within an East European context is open to speculation and debate, particularly if it accepted that there is no dominant model of capitalist work organisation which might represent a template for transforming economies. This paper draws on empirical case study material to appraise the business cultures of four post-socialist Polish enterprises. Findings suggest that ownership, turnover of human capital and management philosophy and ideology represent key factors in the development of market oriented behaviours. However, findings also reinforce the strength and endurance of the socialist culture.

In dieser Arbeit wird die Analyse der Unternehmenskultur von vier polnischen Unternehmen der post-sozialistischen Ära vorgestellt. Was unter einer ,angemessenen' Organisationskultur im Osteuropäischen Kontext zu verstehen ist, darüber kann spekuliert und debattiert werden, besonders dann, wenn kein Standardmodell kapitalistischer Arbeitsorganisation für sich wandelnde Ökonomien existiert. Die Ergebnisse der vorliegenden empirischen Studie legen die Vermutung nahe, daß Eigentum, Humankapital, Managementphilosophie und Ideologie Schlüsselfaktoren bei der Herausbildung marktorientierten Verhaltens darstellen. Andererseits bestätigt sich die nachhaltige Wirksamkeit der sozialistischen Kultur.

\footnotetext{
* Manuscript received: 24.7.1998, revised: 1.10.1999, accepted:8.12.1999;

** Izabela Robinson, born 1952, Senior Lecturer Human Resource Management, School of Business, University College Northampton. Main research interests include; labour relations, organisational transformation, human resource management.
}

Beata Tomczak-Stepien, born 1972, PhD, University of Economics Poznan, International Business Department. Research interests include: micro-theory of transition, change and crisis management, role of organisational culture in enterprise transformation. 


\section{Introduction}

Within western capitalist societies, the development and management of organisational culture is seen as a key component of organisational effectiveness (Denison, 1984, Barney 1986, Williams et al 1993). Similarly, within an East European context it is suggested that successful transformation to free market capitalism requires (in addition to institutional and structural reform) the 'unfreezing' of a dysfunctional socialist culture and the embedding of entrepreneurial attitudes and behaviours (EBRD1997)

However, the concept of organisational culture remains problematic and there are wide-ranging and unresolved debates as to the meaning of organisational culture and the extent to which organisational culture may be successfully manipulated and changed. Moreover, economic and political transformation in post-socialist Central Eastern Europe (CEE) has specific characteristics and features which distinguish it from western restructuring initiatives. The concept of path dependence (Stark 1992) suggests that individual CEE economies will follow different paths to a free market economy which reflect their specific historical, social and cultural legacies. Furthermore, as Whitley (1995, p11) suggests, the corresponding lack of any dominant model of capitalist work organisation which might represent a template for transforming economies reinforces the likelihood that institutional, socio-technical and attitudinal change will be contingency constrained. However, the concept of path dependence needs grounding empirically if it is to provide a meaningful basis for understanding the differential nature of the transformation process in CEE. Path dependence can operate at enterprise level as well as nationally and it is the nature and complexity of transformation at enterprise level that this paper aims to inform. Accordingly, the following structure is adopted: firstly we draw upon existing literature to conceptualise organisational culture and to identify relevant issues in the management and implementation of cultural change. Secondly, we consider literature in relation to the characteristics of organisational culture within Polish socialist firms Thirdly, we present and discuss empirical data in relation to cultural transformation within four post-socialist Polish enterprises and identify significant factors in the adjustment to free market conditions.

\section{Conceptualising organisational culture and the process of culture change}

Western capitalist orthodoxy emphasises the development and management of organisational culture as a key component of organisational effectiveness. The 'excellence' literature, (Kanter 1989, Peters 1987, Peters / Waterman 1982) together with studies of Japanese corporations, (Ouchi 1981, Pascale / Athos 1981) highlighted organisational culture as a key factor in the achievement of competitive business advantage. The emergence of the concept of Human Resource Management (HRM) as an approach to managing the employment 
relationship, has likewise served to emphasise the development of a management ideology and set of practices aimed at creating an appropriate (or changing an inappropriate) organisational culture. HRM policies and practices in areas such as recruitment and selection, socialisation, development, promotion and reward represent mechanisms for translating dominant organisational values into action in a way that supports the business strategy (Keenoy / Anthony 1992).

However, the concept of organisational culture remains problematic and there are wide-ranging and unresolved debates as to what organisational culture is (see e.g. Frost et al 1991) and the extent to which an organisational culture can be managed and changed. Mabey et al (1998) point to a polarised treatment of organisational culture identifying at one extreme a consultancy-based, prescriptive treatment (Willmott 1993, Williams et al 1994) which has an instinctive appeal to managers, particularly those within an individualistic, Anglo-Saxon culture with a bias for action and fascination with business leaders (Lundy / Cowling 1996). At the other extreme are located more theoretical, analytical approaches which illustrate the shortcomings of managerialist prescription. For example as Legge (1995) suggests, a ' positivistic/structural/functionalist' perspective which conceptualises organisational culture as something the organisation 'has' results in a view of organisational culture as 'somehow unitary and the collective conscience of the organisation', (Legge 1995, p186), whereas an alternative view of culture as the product of social interaction, or as something the organisation 'is', emphasises the essentially pluralist nature of organisations, (Legge 1995, p185).

This polarised treatment of organisational culture, reflecting differing epistemological standpoints, likewise extends to debates as to the extent to which organisational culture may be manipulated and changed. Viewed from a pluralist perspective, it is questionable whether organisational culture may be successfully changed (Legge 1995, Ogbonna 1996). Group dynamics processes may be effective in changing attitudes and behaviour and Schein (1987) sees behavioural change as a precursor of cultural change. However, Ogbonna (1996) questions the degree to which employees readily replace existing values with new ones and suggests that employees may learn to adopt the language and behaviour of a new cultural paradigm without fundamentally altering their beliefs and values. Furthermore, the achievement of permanent or deep-rooted change through the use of behavioural change strategies may in itself pose an obstacle to future change.

Pragmatic approaches to changing culture (e.g. through changing job roles, reward strategies and styles of management) on the basis that these will result in culture change likewise equate behavioural change to culture change (or the assumption that behavioural change will result in culture change) and reinforce epistemological questions about the conceptualisation of culture. As Legge 
suggests, it is a structuralist/functionalist approach which emphasises the role of the leader in developing an appropriate collective consensus and suggests a '...culture created by senior management for the lower orders to follow', (Legge 1995,p186). An alternative view of culture as an outcome of social interaction casts doubts over the degree or even the feasibility of senior management's ability to unilaterally change organisational culture. As Legge points out, 'If the corporate culture makes no sense of the organisational realities experienced by the employees other than senior management, it will not become internalised outside that small sub-group', (Legge 1995, p187). A managerial view of culture change serves to explain why much vaunted culture change programmes have been less than successful in winning the hearts and minds of employees within western capitalist organisations, (Lundy / Cowling 1996, p169). The failure of TQM and BPR programmes likewise bear testimony to the mistaken assumption that enterprise culture (in both western and eastern enterprises) can be transformed as quickly and as easily as other organisational assets and resources. (See e.g. Schaffer / Thompson 1992, pp80-89)

Within the transforming economies of CEE it would be naïve, therefore, to assume that organisational culture change would be any less straightforward and unproblematic than within western capitalist organisations. Case studies of strategic change in Polish enterprises emphasise leadership as a key factor in responding to new markets, (Lempkowski 1992, Kozminski 1995), while other commentators point to structural change, management turnover and the removal of senior managers associated with the past regime as key factors in enterprise restructuring and improved enterprise performance (EBRD 1997, Obloj / Thomas 1998). However, many of the pre-1989 elites, power structures and vested interests remain within enterprises and it would be simplistic to underestimate the strength and pervasiveness of the socialist culture. It is to a consideration of the Polish context and the characteristics of state socialism that we now turn.

\section{Characteristics of organisational culture within Polish socialist enterprises}

It has been suggested that the socialist system resulted in a degree of uniformity which militated against the formation of distinct organisational cultures (Czarniawska 1986, p313). This uniformity stemmed from a homogeneity of organisational structures at enterprise level which in turn reflected the economic and political structures of the socialist planning system.

Polish socialist enterprises operated within a hierarchically administered system (union of enterprises, ministries and the Planning Committee), subject to the influence and interference of external power centres (the Communist party and the bureaucratic hierarchy), (Otta 1996, Kostera / Wicha 1996). Thus vertical authority structures were undermined by external agencies with the result that 
management roles, responsibilities and levels of accountability were blurred. Management attention was focused on the supply side of the value chain. Enterprises were not required to sell their output or to finance their production or investment; this was the role of central agencies. However, managers had to ensure they received sufficient supplies of raw materials (including labour) to ensure plan fulfilment. Here two skills were particularly important; getting soft targets which could be easily achieved and stockpiling resources (including labour) to meet tight deadlines, (Peiperl / Estrin 1998) - both depended on connections within the administrative hierarchy, the authorities, the party and the secret police (See Kostera / Proppe / Szatkowski 1995) for the nature of the 'bargaining' role of Polish enterprise managers and the development of reciprocal networks). Kostera and Wicha (1996) describe the environment of Polish socialist enterprises as one of 'cultural schizophrenia' where economic considerations were subjugated to political rationality as the dominant logic. This resulted in 'introversion' in economic terms characterised by an aversion to risk and innovation and unwillingness to take responsibility for economic decisions alongside 'extraversion' within the political arena manifested by close relationships with communist party members and political interest groups. The results were economically damaging - there were few incentives for efficient performance and the short-term orientation worked against risk-taking, innovation and accountability - but they likewise impacted on employee behaviour and work relationships.

Labour relations within Polish socialist firms were likewise shaped by the features of central planning. The combined effects of an illusory shortage of labour, low levels of labour mobility, the socialist ideology of each worker's right to work and basic survival guaranteed by minimum monetary and supplementary social wage, contributed to what Thirkell et al $(1997, \mathrm{p} 19)$ have described as an 'apparently indulgent style of labour relations' whereby supervisors tolerated poor quality work and low levels of labour discipline in return for worker support and flexibility in meeting plan targets and coping with shortages of supplies. Lax labour relations were reinforced by a lack of differentiation of work roles between supervisors and workers and close informal working relationships and were further exacerbated by the repressive political climate of socialist enterprises (Staniszkas 1979). In the absence of a specific workers' culture or organisation or the opportunity for protracted lasting action (as opposed to periods of labour unrest and militancy), Kramer (1995, p78) suggests that Polish workers sensed their limited capability to challenge decision-making at enterprise level and instead used '...their lacklustre job performance as a means of 'exit' from the system'. Such sentiments also support Soulsby and Clark's (1995, p99) conclusion that '...one of the few freedoms of a worker was the 'right' not to work hard'. Not working hard could be considered patriotic because it represented a protest against the socialist system. 
Within this context of worker 'voice' (or lack of), it is appropriate to consider the concept of the state-dependent worker as a normative type of personality created by state socialism. The concept of state-dependent workers relates to the relationship of the worker to the state and to specific work habits and behaviours developed under state socialism which might be said to contribute to an attitudinal and relational legacy which conditions the attitudes of workers and impacts the process of transformation (Miszkala 1996, Staniszkas 1979, Kolarska-Bobinska 1994). To develop the first point; the socialist system of bureaucratic redistribution guaranteed job availability, job security, price stability and a largely egalitarian incomes policy. In doing so it minimised individual risk, generated apathy and passivity of behaviour, promoted attitudes of dependency and created a state of 'learned helplessness' (Miszalska 1996, p47) combined with a distrust of the authorities. This state of psychological resignation manifested itself at the workplace in a 'low-productivity-antiindividualist' mentality (Miszalska 1996, p47), low levels of accountability and initiative, the suppression of difference and interest representation and a low work ethic.

The dismantling of the socialist system and the process of transformation from a centrally planned economy to free market capitalism has had an enormous impact on the functioning of enterprises but the endurance of the socialist culture and an 'old cultural mind frame' (Kostera / Wicha, 1996) is seen as inhibiting effective restructuring and transformation to free market conditions and undermining the effects of technological change. Within this context the concept of organisational culture presents a potentially useful means by which to identify enduring patterns of behaviour from the socialist past but also in demonstrating changed behaviours and their drivers.

\section{Research design}

The aim of this paper was to explore the business cultures of four post-socialist Polish enterprises through the perceptions of those involved in organisational change and transformation. We noted earlier the epistemological difficulties inherent in the conceptualisation of organisational culture (whether this represents behaviour, or values and take-for-granted assumptions) and the consequent lack of a convincing conceptual model that demonstrates how cultural change may be successfully undertaken. We are also mindful of the dangers inherent in a monolithic approach to organisational culture where typologies of culture suggest the imposition of a specific category on an organisation (Handy 1986). We have therefore adopted a process approach, building on the work of Schein (1984), which views organisational culture as a dynamic process and which takes account of the perceptions of participants in the process of culture formation, management and change.

Schein $(1984, \mathrm{p} 3)$ defines organisational culture as: 
'.... a pattern of basic assumptions that a given group has invented, discovered or developed in learning to cope with its problems of external adaptation and internal integration, and that have worked well enough to be considered valid and, therefore, to be taught to those new members s the correct way to perceive, think and feel in relation to those problems'.

Schein's definition recognises that organisations face two fundamental demands - that of external adaptation and internal integration, both of which have particular resonance within transforming economies. External adaptation, Schein suggests, comprises five elements; strategy, goals, means, performance measures and correction systems while internal integration demands shared meanings, definition of organisational boundaries and the legitimisation of power. Schein's definition likewise suggests that culture embraces the concept of morality in determining what is right and appropriate in advocating acceptable behaviours and thus underscores the ethical dimension of culture change and manipulation. Furthermore, he acknowledges that any group within an organisation has the potential for developing its own sub-culture, particularly if it enjoys stability of membership and has a history of joint problem resolution.

We take the view that organisational culture is socially constructed; that it represents both the experience of past actions and acts as a conditioning element of future actions. Thus organisational culture is influenced by the environment and socio-technical systems of the enterprise which are in turn influenced by the values and beliefs of the groups and individuals making up the enterprise. Viewing organisational culture both as an input and as an output suggests that it is likely to be self-perpetuating and resistant to change. A process view of organisational culture demonstrates the challenge facing socialist enterprises in adjusting to free market capitalism and highlights limitations of neo-classical economic orthodoxy which emphasises privatisation, enterprise re-structuring and introduction of hard budget constraints as principal mechanism for the operation of a free market. Organisational transformation is more complex that such analyses suggest.

The research design adopted a case study approach which incorporated participant observation, analysis of company documents, interviews with enterprise directors and senior managers and a survey questionnaire to assess worker perceptions of the prevailing organisational culture together with their perceptions of how this has changed and their aspirations for future change. Fifteen interviews were carried out across the four enterprises with enterprise directors and senior managers. The interview protocol focused on the use of open questions (with prompts on specific issues), hypothetical questions and unpacking critical incidents in order to obtain different perspectives on different issues. A qualitative approach was felt to be more sensitive to processes in terms of how changes had taken place but nevertheless allowed for an holistic view rather than a narrow focus on component elements. In designing questionnaire 
items we were concerned with incorporating features identified within the literature as characteristic of the culture of socialist enterprises. Thus questions focused on worker perceptions of levels of individualism, collectivism and egalitarianism at work, management styles and authority structures. Table 1 summarises the sample size and response rates.

Table 1: Sample size and response rates

\begin{tabular}{|c|c|c|c|}
\hline Enterprise & No. Employed & Sample & Response \\
\hline A & 480 & $48(10 \%)$ & $43(89 \%)$ \\
\hline B & 450 & $98(22 \%)$ & $98(100 \%)$ \\
\hline C & 1,700 & $170(10 \%)$ & $155(67 \%)$ \\
\hline D & 480 & $48(10 \%)$ & $26(54 \%)$ \\
\hline
\end{tabular}

The questionnaire required workers to indicate their perceptions of 'how things were, are and should be' in relation to a number of items. In this way we were able to construct a model of worker views of their preferred organisational culture. Given the emphasis in the literature of the difficulties of rapid culture change we were also able to identify prevailing features of the socialist culture.

The study focused on four post-socialist Polish enterprises which were at different stages in the transformation process. We were concerned with evaluating the purpose and effectiveness of programmes aimed at enabling enterprises to adjust and compete within free market conditions and specifically we were interested in the techniques employed to change organisational culture to match the perceived requirements of the organisational environment. The enterprises within the study were differentiated by size (number of employees), by product and technology used (although all enterprises were within the manufacturing sector), location and nature of ownership. All enterprises shared similar origins as state-owned enterprises and all were concerned with finding a foreign strategic investment partner from the same industry. Two of the enterprises within the study had strategic investors whilst two were still in the process of trying to attract one. Table 2 provides brief details of study enterprises.

\section{Discussion of findings}

The enterprises within the study were at different stages in the transformation from socialist central planning to free market capitalism. Enterprise A was in a very difficult economic situation. In 1989 the enterprise employed 1,200 people 
and this had reduced to 480 but the enterprise was still making losses largely because a substantial part of its production (over 50\%) was geared towards

Table 2: Enterprise Characteristics

\begin{tabular}{|c|c|c|c|c|c|}
\hline Enterprise & Size & Product & \multicolumn{2}{|c|}{ Ownership } & $\begin{array}{c}\text { Characteristics of } \\
\text { Transformation }\end{array}$ \\
\hline \multirow{4}{*}{ A } & \multirow{4}{*}{400} & \multirow{4}{*}{$\begin{array}{l}\text { Manufacture } \\
\text { oil tankers } \\
\& \text { trailers }\end{array}$} & $5^{\text {th }}$ NIF & $33 \%$ & \multirow{4}{*}{$\begin{array}{l}\text { Contraction of operations } \\
\text { (workforce reduction from } \\
1,200 \text { by natural wastage) } \\
\text { sale of machines, land, } \\
\text { buildings } \\
\text { outsourcing of transport, } \\
\text { maintenance }\end{array}$} \\
\hline & & & State Treasury & $27 \%$ & \\
\hline & & & Other NIFs & $23 \%$ & \\
\hline & & & Employees & $17 \%$ & \\
\hline B & 450 & $\begin{array}{l}\text { Manufacture } \\
\text { transmission } \\
\text { stations and } \\
\text { valves for } \\
\text { gas industry }\end{array}$ & \multicolumn{2}{|c|}{$\begin{array}{l}100 \% \text { ownership by } \mathrm{PGNiG} \\
\text { (state owned) }\end{array}$} & $\begin{array}{l}\text { Defensive: } \\
\text { partial rationalisation of } \\
\text { operations (closure of } \\
\text { foundry, outsourcing) } \\
\text { moves towards greater } \\
\text { regulation \& } \\
\text { standardization }\end{array}$ \\
\hline \multirow{5}{*}{$\mathrm{C}$} & \multirow{5}{*}{1700} & \multirow{5}{*}{$\begin{array}{l}\text { Manufacture } \\
\text { loud } \\
\text { speakers }\end{array}$} & \multicolumn{2}{|l|}{ JV - Pioneer } & \multirow{5}{*}{$\begin{array}{l}\text { Defensive } \\
\text { Re-structuring of } \\
\text { production process, } \\
\text { introduction of new, } \\
\text { automated assembly line } \\
\text { ISO } 9000 \\
\text { Search for foreign 'know- } \\
\text { how' }\end{array}$} \\
\hline & & & Treasury & $33 \%$ & \\
\hline & & & Pioneer & $11 \%$ & \\
\hline & & & Employees & $20 \%$ & \\
\hline & & & $\begin{array}{l}\text { Bank \& Life } \\
\text { Ass. Comp. }\end{array}$ & $1 \%$ & \\
\hline \multirow{4}{*}{ D } & \multirow{4}{*}{480} & \multirow{4}{*}{$\begin{array}{l}\text { Manufacture } \\
\text { integrated } \\
\text { systems for } \\
\text { gas \& water } \\
\text { supply }\end{array}$} & \multicolumn{2}{|l|}{ JV } & \multirow{4}{*}{$\begin{array}{l}\text { Heavy investment by } \\
\text { parent in production } \\
\text { technology, computer } \\
\text { systems, management \& } \\
\text { staff training } \\
\text { ISO } 9000 \text { Quality circles } \\
50 \% \text { staff t/o since } 1991 \\
\text { New functions - sales, } \\
\text { marketing, }\end{array}$} \\
\hline & & & Danish Co. & $70 \%$ & \\
\hline & & & Treasury & $18 \%$ & \\
\hline & & & Employees & 2 & \\
\hline
\end{tabular}

military production and repair and there had been no substitution for this loss of production. Since 1989 the enterprise had been fighting to survive through a variety of cost-cutting and restructuring measures. The restructuring process, which had been largely financed internally and which had required enormous effort on the part of the workforce had been of limited effectiveness. Worker 
frustrations and disillusionment with the restructuring process were evident in questionnaire responses (see Table 3) which indicated that workers felt that things were better five years ago than currently. For this enterprise a strategic investor represented the only way out of its economic crisis but despite widespread recognition of this situation, there were considerable fears about the implications for job security and remuneration particularly amongst administrative staff. Many skilled and competent production workers had left the enterprise and secured employment elsewhere but administrative staff were particularly vulnerable.

Enterprise B also did not have a strategic investor but here the situation was slightly different because the enterprise was part of a much larger company, PGNiG which dealt with gas extraction and distribution. The gas industry was regarded as of strategic importance to the economy and the parent company thus enjoyed the protection of a strong entry barrier. This protection did not extend to Enterprise B who produce transmission stations and valves and who are subject to competition, but nevertheless, the parent company has sheltered the enterprise from the exigencies of the market and had provided funding for restructuring initiatives such as modernising machinery, the introduction of computerised systems and large-scale training programmes. The enterprise began looking for a strategic investor two years ago; the driver was awareness of growing competition within this industrial sector coupled with the need for a technologically and economically sound partner to support the enterprise's diverse activities. Through a process of elimination, the enterprise began to cooperate with a German concern as a pre-requisite for acquisition. The nature of this co-operation involved exchange visits by managers and workers and a sharing of information and know-how.

In relation to worker attitudes there was a similar apprehension on the part of administrative workers to organisational restructuring but the key opponents of the acquisition process were the trades unions who feared substantial job losses particularly as small scale job losses had already been experienced as part of the restructuring process. A large proportion of the workforce, particularly older workers believed that the enterprise was in a strong enough position to survive and prosper independently within a free market which represented an optimistic scenario. Within the remaining two enterprises there was evidence of cooperation of Polish workers and managers with foreign owners and partners. This is not to say that the initial stages of working with a foreign investor were free from conflict and tension and that Polish managers and workers had to adjust to new ways of working and managing. Strategies for co-operation varied in their nature and scope.

Enterprise $\mathrm{C}$ was a large monopolistic enterprise employing 1,700 people in the production of loudspeakers and was one of the first enterprises privatised by public sale of share on the Polish stock exchange following a joint venture with 
a Japanese investor. The Japanese investor had incrementally increased financial shareholding and involvement in business decision-making but this was not reflected in a clear strategic direction for the enterprise. The Japanese investor had concentrated on the education and training of employees on new production lines and in emphasising quality and continuous improvement issues. They saw their role as bottom-up socialisation of the workforce in Japanese styles of working whilst difficult economic decisions about the functioning of the enterprise (e.g. decisions about job losses) were left to the Polish management team.

By contrast to the Japanese approach, Enterprise D had adopted a clearly defined strategic vision and direction based on developing market share and exploiting the advantages of low cost production. Enterprise D manufactured integrated systems for the supply of gas a water to utility companies and entered into a joint venture agreement with a Danish investor in 1991. The Danish partner had invested heavily in a widespread programme of technological change and the development of a distribution network backed up by large scale training and development programmes. Entry barriers in this market were low but the enterprise competed on the basis of providing an integrated technology with comprehensive pre and post-sales service which gave it a competitive advantage and the company has enjoyed rapid expansion of the Polish and East European markets. The workforce numbered 480 and was predominantly young, qualified and relatively highly paid. Within Enterprise D the workforce were enthusiastic and supportive of the joint venture agreement largely because of the personal style and interpersonal skills of the enterprise director who was instrumental in selling the advantages of foreign partnership to the workforce. During the period of the joint venture there had been no reduction in staffing levels and the workforces had actually grown by $30 \%$ through the recruitment of young, qualified people into newly created positions within finance, sales and marketing functions. Initial enthusiasm for the joint venture had been sustained throughout the eight year period of foreign investment and workers at all levels were very positive about their role within the enterprise.

Table 3 presents questionnaire extracts which reflect worker perceptions of aspects of organisational culture and how this has changed within enterprises studied. Responses also indicate worker aspirations for the future. 
Table 3: Extracts from questionnaire showing worker perceptions of how things were, are and should be.

Enterprise A

\begin{tabular}{|c|c|c|c|c|c|c|c|c|c|}
\hline \multirow[t]{2}{*}{ Question } & \multicolumn{3}{|c|}{$\begin{array}{l}\text { People co-operate to } \\
\text { solve problems }\end{array}$} & \multicolumn{3}{|c|}{$\begin{array}{l}\text { People are } \\
\text { responsible for } \\
\text { results }\end{array}$} & \multicolumn{3}{|c|}{$\begin{array}{l}\text { People are able to } \\
\text { make decisions in } \\
\text { their work }\end{array}$} \\
\hline & \multicolumn{2}{|c|}{5 yrs ago } & now & $\begin{array}{l}5 \text { yrs } \\
\text { ago }\end{array}$ & now & $\begin{array}{l}\text { should } \\
\text { be }\end{array}$ & $\begin{array}{c}5 y r s \\
\text { ago }\end{array}$ & Now & $\begin{array}{l}\text { should } \\
\text { be }\end{array}$ \\
\hline To no/small degree & \multicolumn{2}{|c|}{$42 \%$} & $66 \%$ & $28 \%$ & $47 \%$ & $9 \%$ & $70 \%$ & $76 \%$ & $18 \%$ \\
\hline To adequate degree & \multicolumn{2}{|c|}{$16 \%$} & $16 \%$ & $35 \%$ & $20 \%$ & - & $19 \%$ & $9 \%$ & $9 \%$ \\
\hline To great degree & \multicolumn{2}{|c|}{$42 \%$} & $18 \%$ & $37 \%$ & $33 \%$ & $91 \%$ & $11 \%$ & $15 \%$ & $73 \%$ \\
\hline \multirow[t]{2}{*}{ Question } & \multicolumn{3}{|c|}{$\begin{array}{l}\text { People are free to } \\
\text { exercise individual } \\
\text { initiative }\end{array}$} & \multicolumn{3}{|c|}{$\begin{array}{l}\text { People build close } \\
\text { working } \\
\text { relationships }\end{array}$} & \multicolumn{3}{|c|}{$\begin{array}{l}\text { People have to abide } \\
\text { by rules \& } \\
\text { regulations }\end{array}$} \\
\hline & $\begin{array}{l}5 \text { yrs } \\
\text { ago }\end{array}$ & No & $\begin{array}{c}\text { should } \\
\text { be }\end{array}$ & $\begin{array}{l}5 \text { yrs } \\
\text { ago }\end{array}$ & Now & $\begin{array}{l}\text { should } \\
\text { be }\end{array}$ & $\begin{array}{c}5 \text { yrs } \\
\text { ago }\end{array}$ & Now & $\begin{array}{l}\text { should } \\
\text { be }\end{array}$ \\
\hline To no/small degree & $42 \%$ & $44^{c}$ & $7 \%$ & $49 \%$ & $63 \%$ & $7 \%$ & $12 \%$ & $26 \%$ & $14 \%$ \\
\hline To adequate degree & $33 \%$ & 28 & $2 \%$ & $21 \%$ & $16 \%$ & $7 \%$ & $18 \%$ & $19 \%$ & $14 \%$ \\
\hline To great degree & $25 \%$ & 28 & $91 \%$ & $30 \%$ & $21 \%$ & $86 \%$ & $60 \%$ & $55 \%$ & $72 \%$ \\
\hline \multirow[t]{2}{*}{ Question } & \multicolumn{3}{|c|}{$\begin{array}{l}\text { People take } \\
\text { responsibility for } \\
\text { their own } \\
\text { development }\end{array}$} & \multicolumn{3}{|c|}{$\begin{array}{l}\text { People take } \\
\text { responsibility for } \\
\text { colleagues' } \\
\text { development }\end{array}$} & \multicolumn{3}{|c|}{$\begin{array}{l}\text { There is a strong link } \\
\text { between performance } \\
\text { \& work }\end{array}$} \\
\hline & $\begin{array}{l}5 \text { yrs } \\
\text { ago }\end{array}$ & No & $\begin{array}{c}\text { should } \\
\text { be }\end{array}$ & $\begin{array}{l}5 \text { yrs } \\
\text { ago }\end{array}$ & Now & $\begin{array}{l}\text { should } \\
\text { be }\end{array}$ & $\begin{array}{c}5 \text { yrs } \\
\text { ago }\end{array}$ & Now & $\begin{array}{l}\text { should } \\
\text { be }\end{array}$ \\
\hline To no/small degree & $42 \%$ & 42 & $7 \%$ & $67 \%$ & $75 \%$ & $24 \%$ & $77 \%$ & $90 \%$ & $9 \%$ \\
\hline To adequate degree & $21 \%$ & 23 & $9 \%$ & $19 \%$ & $12 \%$ & $16 \%$ & $16 \%$ & $2 \%$ & - \\
\hline To great degree & $37 \%$ & $35^{\circ}$ & $84 \%$ & $14 \%$ & $13 \%$ & $60 \%$ & $7 \%$ & $8 \%$ & $91 \%$ \\
\hline
\end{tabular}


Enterprise B

\begin{tabular}{|c|c|c|c|c|c|c|c|c|c|}
\hline \multirow[t]{2}{*}{ Question } & \multicolumn{3}{|c|}{$\begin{array}{l}\text { People co-operate to } \\
\text { solve problems }\end{array}$} & \multicolumn{3}{|c|}{$\begin{array}{l}\text { People are } \\
\text { responsible for } \\
\text { results }\end{array}$} & \multicolumn{3}{|c|}{$\begin{array}{l}\text { People are able to } \\
\text { make decisions in } \\
\text { their work }\end{array}$} \\
\hline & \multicolumn{2}{|c|}{5 yrs ago } & now & $\begin{array}{l}5 \text { yrs } \\
\text { ago }\end{array}$ & now & $\begin{array}{c}\text { should } \\
\text { be }\end{array}$ & $\begin{array}{c}5 y r s \\
\text { ago }\end{array}$ & Now & $\begin{array}{l}\text { should } \\
\text { be }\end{array}$ \\
\hline To no/small degree & \multicolumn{2}{|c|}{$23 \%$} & $10 \%$ & $31 \%$ & $11 \%$ & $1 \%$ & $61 \%$ & $19 \%$ & $4 \%$ \\
\hline To adequate degree & \multicolumn{2}{|c|}{$40 \%$} & $38 \%$ & $42 \%$ & $30 \%$ & $3 \%$ & $28 \%$ & $34 \%$ & $9 \%$ \\
\hline To great degree & \multicolumn{2}{|c|}{$37 \%$} & $52 \%$ & $27 \%$ & $59 \%$ & $96 \%$ & $11 \%$ & $47 \%$ & $87 \%$ \\
\hline \multirow[t]{2}{*}{ Question } & \multicolumn{3}{|c|}{$\begin{array}{l}\text { People are free to } \\
\text { exercise individual } \\
\text { initiative }\end{array}$} & \multicolumn{3}{|c|}{$\begin{array}{l}\text { People build close } \\
\text { working } \\
\text { relationships }\end{array}$} & \multicolumn{3}{|c|}{$\begin{array}{l}\text { People have to abide } \\
\text { by rules } \& \\
\text { regulations }\end{array}$} \\
\hline & $\begin{array}{l}5 y r s \\
\text { ago }\end{array}$ & Nov & $\begin{array}{c}\text { should } \\
\text { be }\end{array}$ & $\begin{array}{l}5 \text { yrs } \\
\text { ago }\end{array}$ & Now & $\begin{array}{l}\text { should } \\
\text { be }\end{array}$ & $\begin{array}{c}5 \text { yrs } \\
\text { ago }\end{array}$ & Now & $\begin{array}{l}\text { should } \\
\text { be }\end{array}$ \\
\hline To no/small degree & $46 \%$ & $5 \%$ & $1 \%$ & $31 \%$ & $14 \%$ & - & $24 \%$ & $5 \%$ & - \\
\hline To adequate degree & $33 \%$ & $30 \%$ & $6 \%$ & $39 \%$ & $34 \%$ & $2 \%$ & $42 \%$ & $21 \%$ & $8 \%$ \\
\hline To great degree & $21 \%$ & $65 \%$ & $93 \%$ & $30 \%$ & $52 \%$ & $98 \%$ & $34 \%$ & $74 \%$ & $92 \%$ \\
\hline \multirow[t]{2}{*}{ Question } & \multicolumn{3}{|c|}{$\begin{array}{l}\text { People take } \\
\text { responsibility for } \\
\text { their own } \\
\text { development }\end{array}$} & \multicolumn{3}{|c|}{$\begin{array}{l}\text { People take } \\
\text { responsibility for } \\
\text { colleagues' } \\
\text { development }\end{array}$} & \multicolumn{3}{|c|}{$\begin{array}{l}\text { There is a strong link } \\
\text { between performance } \\
\text { \& work }\end{array}$} \\
\hline & $\begin{array}{l}5 \text { yrs } \\
\text { ago }\end{array}$ & Nov & $\begin{array}{c}\text { should } \\
\text { be }\end{array}$ & $\begin{array}{c}5 \text { yrs } \\
\text { ago }\end{array}$ & Now & $\begin{array}{l}\text { should } \\
\text { be }\end{array}$ & $\begin{array}{c}5 \text { yrs } \\
\text { ago }\end{array}$ & Now & $\begin{array}{c}\text { should } \\
\text { be }\end{array}$ \\
\hline To no/small degree & $38 \%$ & $4 \%$ & - & $55 \%$ & $22 \%$ & $6 \%$ & $55 \%$ & $42 \%$ & $4 \%$ \\
\hline To adequate degree & $42 \%$ & $32 \%$ & $11 \%$ & $29 \%$ & $37 \%$ & $15 \%$ & $30 \%$ & $29 \%$ & $4 \%$ \\
\hline To great degree & $20 \%$ & $64 \%$ & $89 \%$ & $16 \%$ & $41 \%$ & $79 \%$ & $15 \%$ & $29 \%$ & $92 \%$ \\
\hline
\end{tabular}


Enterprise $C$

\begin{tabular}{|c|c|c|c|c|c|c|c|c|c|}
\hline \multirow[t]{2}{*}{ Question } & \multicolumn{3}{|c|}{$\begin{array}{l}\text { People co-operate to } \\
\text { solve problems }\end{array}$} & \multicolumn{3}{|c|}{$\begin{array}{l}\text { People are } \\
\text { responsible for } \\
\text { results }\end{array}$} & \multicolumn{3}{|c|}{$\begin{array}{l}\text { People are able to } \\
\text { make decisions in } \\
\text { their work }\end{array}$} \\
\hline & \multicolumn{2}{|c|}{5 yrs ago } & Now & $\begin{array}{l}5 \text { yrs } \\
\text { ago }\end{array}$ & now & $\begin{array}{c}\text { should } \\
\text { be }\end{array}$ & $\begin{array}{c}5 y r s \\
\text { ago }\end{array}$ & Now & $\begin{array}{l}\text { should } \\
\text { be }\end{array}$ \\
\hline To no/small degree & \multicolumn{2}{|c|}{$26 \%$} & $31 \%$ & $25 \%$ & $18 \%$ & $4 \%$ & $61 \%$ & $48 \%$ & $13 \%$ \\
\hline To adequate degree & \multicolumn{2}{|c|}{$35 \%$} & $31 \%$ & $39 \%$ & $21 \%$ & $6 \%$ & $26 \%$ & $31 \%$ & $23 \%$ \\
\hline To great degree & \multicolumn{2}{|c|}{$39 \%$} & $38 \%$ & $44 \%$ & $35 \%$ & $90 \%$ & $13 \%$ & $21 \%$ & $64 \%$ \\
\hline \multirow[t]{2}{*}{ Question } & \multicolumn{3}{|c|}{$\begin{array}{l}\text { People are free to } \\
\text { exercise individual } \\
\text { initiative }\end{array}$} & \multicolumn{3}{|c|}{$\begin{array}{l}\text { People build close } \\
\text { working } \\
\text { relationships }\end{array}$} & \multicolumn{3}{|c|}{$\begin{array}{l}\text { People have to abide } \\
\text { by rules } \& \\
\text { regulations }\end{array}$} \\
\hline & $\begin{array}{l}5 y r s \\
\text { ago }\end{array}$ & No & $\begin{array}{c}\text { should } \\
\text { be }\end{array}$ & $\begin{array}{l}5 \text { yrs } \\
\text { ago }\end{array}$ & Now & $\begin{array}{l}\text { should } \\
\text { be }\end{array}$ & $\begin{array}{c}5 \text { yrs } \\
\text { ago }\end{array}$ & Now & $\begin{array}{c}\text { should } \\
\text { be }\end{array}$ \\
\hline To no/small degree & $18 \%$ & $18^{\circ}$ & $8 \%$ & $30 \%$ & $31 \%$ & $6 \%$ & $14 \%$ & $8 \%$ & $5 \%$ \\
\hline To adequate degree & $43 \%$ & $36^{\circ}$ & $6 \%$ & $36 \%$ & $32 \%$ & $5 \%$ & $15 \%$ & $8 \%$ & $7 \%$ \\
\hline To great degree & $39 \%$ & $46^{\circ}$ & $86 \%$ & $34 \%$ & $37 \%$ & $89 \%$ & $71 \%$ & $84 \%$ & $88 \%$ \\
\hline \multirow[t]{2}{*}{ Question } & \multicolumn{3}{|c|}{$\begin{array}{l}\text { People take } \\
\text { responsibility for } \\
\text { their own } \\
\text { development }\end{array}$} & \multicolumn{3}{|c|}{$\begin{array}{l}\text { People take } \\
\text { responsibility for } \\
\text { colleagues' } \\
\text { development }\end{array}$} & \multicolumn{3}{|c|}{$\begin{array}{l}\text { There is a strong link } \\
\text { between performance } \\
\text { \& work }\end{array}$} \\
\hline & $\begin{array}{l}5 y r s \\
\text { ago }\end{array}$ & No & $\begin{array}{c}\text { should } \\
\text { be }\end{array}$ & $\begin{array}{l}5 \text { yrs } \\
\text { ago }\end{array}$ & Now & $\begin{array}{l}\text { should } \\
\text { be }\end{array}$ & $\begin{array}{c}5 \text { yrs } \\
\text { ago }\end{array}$ & Now & $\begin{array}{c}\text { should } \\
\text { be }\end{array}$ \\
\hline To no/small degree & $30 \%$ & $20^{\circ}$ & $5 \%$ & $51 \%$ & $53 \%$ & $20 \%$ & $63 \%$ & $54 \%$ & $11 \%$ \\
\hline To adequate degree & $34 \%$ & $34^{\circ}$ & $16 \%$ & $33 \%$ & $31 \%$ & $29 \%$ & $18 \%$ & $21 \%$ & $5 \%$ \\
\hline To great degree & $36 \%$ & $46^{\circ}$ & $79 \%$ & $16 \%$ & $16 \%$ & $51 \%$ & $19 \%$ & $25 \%$ & $84 \%$ \\
\hline
\end{tabular}


Enterprise D

\begin{tabular}{|c|c|c|c|c|c|c|c|c|c|}
\hline \multirow[t]{2}{*}{ Question } & \multicolumn{3}{|c|}{$\begin{array}{l}\text { People co-operate to } \\
\text { solve problems }\end{array}$} & \multicolumn{3}{|c|}{$\begin{array}{l}\text { People are } \\
\text { responsible for } \\
\text { results }\end{array}$} & \multicolumn{3}{|c|}{$\begin{array}{l}\text { People are able to } \\
\text { make decisions in } \\
\text { their work }\end{array}$} \\
\hline & \multicolumn{2}{|c|}{5 yrs ago } & now & $\begin{array}{l}5 \text { yrs } \\
\text { ago }\end{array}$ & now & $\begin{array}{l}\text { should } \\
\text { be }\end{array}$ & $\begin{array}{c}5 y r s \\
\text { ago }\end{array}$ & Now & $\begin{array}{l}\text { should } \\
\text { be }\end{array}$ \\
\hline To no/small degree & \multicolumn{2}{|c|}{$43 \%$} & - & $19 \%$ & - & - & $62 \%$ & $10 \%$ & - \\
\hline To adequate degree & \multicolumn{2}{|c|}{$24 \%$} & $48 \%$ & $38 \%$ & $24 \%$ & $10 \%$ & $38 \%$ & $38 \%$ & $10 \%$ \\
\hline To great degree & \multicolumn{2}{|c|}{$34 \%$} & $52 \%$ & $43 \%$ & $76 \%$ & $90 \%$ & - & $52 \%$ & $90 \%$ \\
\hline \multirow[t]{2}{*}{ Question } & \multicolumn{3}{|c|}{$\begin{array}{l}\text { People are free to } \\
\text { exercise individual } \\
\text { initiative }\end{array}$} & \multicolumn{3}{|c|}{$\begin{array}{l}\text { People build close } \\
\text { working } \\
\text { relationships }\end{array}$} & \multicolumn{3}{|c|}{$\begin{array}{l}\text { People have to abide } \\
\text { by rules \& } \\
\text { regulations }\end{array}$} \\
\hline & $\begin{array}{l}5 y r s \\
\text { ago }\end{array}$ & Nov & $\begin{array}{c}\text { should } \\
\text { be }\end{array}$ & $\begin{array}{l}5 \text { yrs } \\
\text { ago }\end{array}$ & Now & $\begin{array}{l}\text { should } \\
\text { be }\end{array}$ & $\begin{array}{c}5 \text { yrs } \\
\text { ago }\end{array}$ & Now & $\begin{array}{l}\text { should } \\
\text { be }\end{array}$ \\
\hline To no/small degree & $29 \%$ & - & - & $34 \%$ & $19 \%$ & - & $29 \%$ & - & - \\
\hline To adequate degree & $33 \%$ & $24 \%$ & $5 \%$ & $29 \%$ & $19 \%$ & $5 \%$ & $24 \%$ & $14 \%$ & $10 \%$ \\
\hline To great degree & $38 \%$ & $76^{\circ}$ & $95 \%$ & $37 \%$ & $62 \%$ & $95 \%$ & $48 \%$ & $86 \%$ & $90 \%$ \\
\hline \multirow[t]{2}{*}{ Question } & \multicolumn{3}{|c|}{$\begin{array}{l}\text { People take } \\
\text { responsibility for } \\
\text { their own } \\
\text { development }\end{array}$} & \multicolumn{3}{|c|}{$\begin{array}{l}\text { People take } \\
\text { responsibility for } \\
\text { colleagues' } \\
\text { development }\end{array}$} & \multicolumn{3}{|c|}{$\begin{array}{l}\text { There is a strong link } \\
\text { between performance } \\
\text { \& work }\end{array}$} \\
\hline & $\begin{array}{l}5 y r s \\
\text { ago }\end{array}$ & Nov & $\begin{array}{c}\text { should } \\
\text { be }\end{array}$ & $\begin{array}{l}5 \text { yrs } \\
\text { ago }\end{array}$ & Now & $\begin{array}{l}\text { should } \\
\text { be }\end{array}$ & $\begin{array}{c}5 y r s \\
\text { ago }\end{array}$ & Now & $\begin{array}{l}\text { should } \\
\text { be }\end{array}$ \\
\hline To no/small degree & $38 \%$ & $5 \%$ & - & $66 \%$ & $24 \%$ & $15 \%$ & $57 \%$ & $19 \%$ & - \\
\hline To adequate degree & $33 \%$ & $33 \%$ & $10 \%$ & $24 \%$ & $66 \%$ & $33 \%$ & $19 \%$ & $24 \%$ & $5 \%$ \\
\hline To great degree & $29 \%$ & $62 \%$ & $90 \%$ & $10 \%$ & $10 \%$ & $52 \%$ & $24 \%$ & $57 \%$ & $95 \%$ \\
\hline
\end{tabular}

It is possible to conceptualise the transformation process from a socialist culture to a market led, entrepreneurial culture as a continuum with the ultimate goal of what EBRD (1997) describe as 'deep restructuring'. Viewed in this way the enterprises within the study can be viewed as occupying different positions along this continuum. We have identified key factors impacting on this progression and driving culture change as ownership (in particular foreign ownership), management style and ideology and strategies for performance and 
reward management. These factors are not mutually exclusive but rather reinforce each other in the development of a new cultural paradigm.

\section{Ownership as a factor in cultural change}

The enterprises within the study were at different stages in the transition from a socialist to a market led culture. At one extreme Enterprise A faced an uncertain and insecure future particularly if NIF support was not forthcoming. This uncertainty was evident in worker questionnaire responses where replies on all items suggested a perception that things were worse now than they had been five years ago. In particular workers felt that levels of accountability, co-operation and teamworking had deteriorated. Workers at Enterprise A also reported the widest discrepancy in their perceptions of the present and their aspirations for the future, particularly in relation to the recognition and reward of individual performance and responsibility at work. At the other extreme, Enterprise D represented an example of a commercially successful and prospering enterprise which had undergone a radical transformation in all aspects of its operation and, of all the study enterprises, could be said to approximate to an entrepreneurial, market driven organisational culture. A key factor in this transformation had been the role of FDI and know-how with practically all innovations (production technology, logistic systems, integrated computer information systems, managerial techniques and processes) having been brought in from the parent company. Such innovations underpinned by strategies for recruitment, development and reward had been influential in hastening successful adjustment to a market economy.

Enterprises B and C had made some 'defensive' adjustment measures in response to competitive market pressures and a hardening of budget constraints. Enterprise B were planning a rationalisation of operations through the outsourcing of ancillary activities, while Enterprise $\mathrm{C}$ were anticipating a restructuring of production processes through the introduction of new, automated assembly lines. Managers within both of these enterprises saw restructuring as an expansion of operations to exploit the profit potential of the enterprise as the appropriate response to competitive market pressures (as opposed to a contraction of operations as at Enterprise A). However, neither enterprise had made any significant attempts at 'deep' organisational restructuring. Functional hierarchies remained in place and there had been limited initiatives to change working methods or to improve existing resources. Worker perceptions highlighted improvements in opportunities for individual development and teamworking but also indicated wide discrepancies between existing arrangements and worker aspirations particularly in relation to the development of effective working relationships, levels of responsibility and accountability and involvement in decision-making. 


\section{Management styles and ideology}

We found little evidence within the enterprises studied of a rational, strategic, management driven approach to culture change. Within Enterprise D, the impetus for a clearly defined vision of the future was provided by the foreign parent company and was underpinned by a strategic business planning and budgeting process implemented by appropriately trained and qualified personnel. Within the remaining enterprises, managers demonstrated a lack of clarity of organisational goals and strategic direction. They had an incomplete picture of business strategy, strategic management or how to address employee expectations as expressed through questionnaire responses. Through interviews with senior managers we detected that Polish managers had enthusiastically adopted the rhetoric and vocabulary of western management (regardless of the degree of foreign involvement) but that this has had a largely symbolic value in enabling them to re-define their role and legitimising their authority within free market conditions. The following quotation is illustrative of how western management rhetoric has enabled Polish managers to nail their colours to the mast of free market capitalism:

'I consider myself to be a young man in my outlook although I am 45 years old. I am now working in the 'second' company, as this is the best way to describe it. Previously the enterprise was a state monopolist, customers were an afterthought; for western managers this would be inconceivable. I had the good fortune to study western organisational structures and systems at university and wrote my thesis on this subject. I took every opportunity to visit England. I tired, but was unable to apply the practical principles here because of the inertia of the state enterprise system. Now (following his appointment as Enterprise Director in 1994), I am able to influence the organisation and apply the principles of a healthy organisation'. (Enterprise Director, Enterprise A).

However, to see the adoption by Polish managers of the rhetoric of western managers as evidence of any real change in management roles and behaviour is superficial and premature. As suggested earlier, managers had an unclear and incomplete picture of business strategy and lacked confidence in their own ability and expertise to implement change which manifested itself in the tendency to seek outside help and know-how through seeking strategic foreign investors and the use of academics and consultants. Whilst privatisation may have removed the political and economic straightjacket of socialism, insider control within enterprises, has meant that the informal networks and reciprocal arrangements characteristic of the management of state owned enterprises have been largely preserved. 


\section{Management strategy for the development of human resources.}

Despite the differences between enterprises outlined earlier, workers across all enterprises demonstrated a large degree of consistency in respect of their perceptions of 'how things should be' and the characteristics of their preferred organisational culture. Particularly significant were issues in relation to people being free to exercise initiative at work, taking responsibility for their own development, building close working relationships and linking individual performance to rewards. Worker preferences indicated support for a strong culture which was individualist rather than collectivist in character. In addition, workers saw the need for clear rules, policies and procedures governing their role at work and their responsibilities, and emphasised the social role of the enterprise in meeting welfare needs. In one sense this can be seen as feature of the socialist legacy which provided extensive social protection but is also a feature of the employment policies of foreign organisations although in the latter case protection is dependent on performance. In contrast with the collectivist provision of social protection within socialist firms, such provision by foreign firms is used as a motivational tool and for many Polish workers represents an attractive approach. Anecdotal evidence suggests that Polish workers respond very positively to the activities of foreign enterprises such as foreign trips, parties and social events.

In order to probe worker aspirations we asked additional questions in relation to what workers felt would make them more effective in their jobs and again we found a high level of consistency in responses across all four enterprises. 84\% highlighted 'better resources to work with'; $75 \%$ having clearer goals and targets to work to; $74 \%$ better understanding of how their work was evaluated; $72 \%$ better understanding of the organisation's purpose and mission; $71 \%$ greater freedom to use individual initiative and judgement at work. Whilst caution needs to be exercised in relation to the interpretation of such aspirations of the workforces within the enterprises studied, our findings do seem to reflect a reaction to the uniformity of a socialist culture together with a desire by individuals across all enterprises to have a greater degree of involvement and influence over their work and a greater level of responsibility. To this extent findings indicate a preparedness for change on the part of the workforce.

However, despite formal institutional arrangements for employee representation and the existence of trade unions within all of the enterprises studied we found little evidence of a collaborative, 'social partnership' approach or any desire by managers to engage workers in the process of organisational transformation. As a senior manager at Enterprise C commented, ' as a good capitalist, I see no role for the trade unions in the process (of organisational transformation)'. Enterprise $\mathrm{D}$, through the use of quality circles, direct forms of communication and increased delegation could be said to be moving in the direction of a more participative management style. However, within the remaining enterprises the 
management style remained largely authoritative and there was no evidence to support a management ideology that saw human resources as a source of competitive advantage. Nevertheless, we found no evidence that employees were frightened of, or intimidated by their managers, but rather that both workers and managers were disempowered by the need to follow established rules and procedures, although paradoxically, there was widespread agreement that such regulations were necessary and appropriate. Within Enterprise B the emphasis in responding to competitive market pressures was to increase the use of management regulation and measurement. In this context bureaucratic rules and procedures represented less an effective form of management control as an opportunity to maintain the status quo and as a rationalisation for mistakes and inaction.

\section{Strategies for performance and reward management}

Reward and remuneration arrangements for workers under the socialist regime were very flat and undifferentiated. Within the enterprises studied, only enterprise D had used the leverage of higher wages and performance based pay. Although pay rates remained considerably lower than within the parent company's operations in western Europe, wages within Enterprise D were relatively high for the locality and twice the national average. With the exception of Enterprise D, there was no evidence within the reaming enterprises of any serious control or motivation systems in place which resulted in a continuation of a somewhat laissez faire approach to discipline and the management of the employment relationship. Such a situation mirrored the socialist past and reflected a lack of managerial expertise and experience in creating effective internal performance management arrangements. However, it also reflected wider social attitudes and values. It was suggested to us that Polish people do not differentiate between their work and private lives; that employees know each other as friends and neighbours within the same community and consider it inappropriate to make judgements and possibly reprimand friends.

\section{Conclusion}

Within the enterprises studied, Enterprise D demonstrated the most persuasive evidence of deep organisational restructuring and cultural adaptation to free market conditions. This was achieved through foreign intervention and investment and underpinned by extensive training and development programmes. However,

rapid organisational change within this enterprise took place not only because of changes in institutional processes but because both parties were willing to adapt and to co-operate with each other. This lends support to the view of a 'third way' or an adjustment to changed market conditions which reflects neither 
a complete emulation nor rejection of foreign approaches but the possibility and value of a joint approach which takes account of the particular circumstances of the enterprise. Such an approach reflects the value of a 'path dependency' approach to the study of transforming enterprises. Within the remaining three enterprises studied it was difficult to point to any large degree of cultural change or adjustment. Privatisation may have removed the political and economic straightjacket within which socialist enterprises had to operate and thus given enterprises a greater degree of autonomy but existing structures, hierarchies, relationships and ways of working remained largely unchanged. We conclude therefore that the speed and consistency of the direction of cultural change and adaptation is more pronounced in situations where there are strong external influences in the form of foreign investment and involvement, clarity of organisational goals and strategic direction and an acceptance of the need to change.

Despite difference between the enterprises studied, there was a high degree of consistency in worker perceptions of the characteristics of a market oriented enterprise. These characteristics were felt to include a transformational element in leadership style, a more individualistic employment relationship which included a link between individual performance and reward, higher levels of worker involvement in decision-making and improved levels of cross functional co-operation and teamworking. Changing organisational culture is a lengthy and complex process but our findings indicate that this process may be hastened through the creation and articulation of clear organisational goals and the direction of their achievement, improved communication throughout the organisation and increasing worker accountability through improved training and development programmes and transparent systems of performance review and reward. Given the characteristics of the socialist legacy, a key factor in the successful implementation of the identified strategy is the constant reinforcement of strategic goals and the behaviours required to achieve these in order for these to be internalised by workers.

\section{References}

Barney, J. (1986): Organisational Culture: Can it be a Sustained Source of Competitive Advantage? Academy of Management Review. 11.3. pp. 656-665.

Czarniawska, B. (1986): The Management of Meaning in the Polish Crisis. Journal of Management Studies. 23.3. pp.313-31.

Denison, D. (1984): Bringing Corporate Culture to the Bottom Line. Organisational Dynamics. 12. pp. 5-33.

European Bank of Reconstruction and Development (1997): Transition Report.

Frost, P. / Moore, L. / Lundberg, C. / Martin, J. (1991): Introduction. in Frost et al (eds) Reframing Organisational Culture. Newbury Park . CA / Sage. 
Handy, C. (1986): Understanding Organisations. Middlesex / Penguin.

Kanter, R. (1989): When Giants Learn to Dance. New York/ Simon / Schuster.

Keenoy, T. / Anthony, P. HRM: Metaphor, Meaning and Morality. in Blyton, P. / Turnbull, P. (eds) Re-assessing Human Resource Management. London / Sage.

Kolarska-Bobinska, L. (1994): Aspirations, Values and Interests. Warsaw / IFIS.

Kostera, M. / Proppe, M. / Szatkowski, M. (1995): Staging the New Romantic Hero in the Old Cynical Theatre: On Managers, Roles and Change in Poland. Journal of Organisational Behaviour. 16, pp. 628-630.

Kostera, M. / Wicha, M. (1996): The 'Divided Self' of Polish State Owned Enterprises: The Culture of Organising. Organisation Studies. 17.1. pp.83-105.

Kozminski, A. (1995): From the Communist Nomenklatura to Transformational

Leadership: The Role of Management in the Post-Communist Enterprises. In Grancelli, B. (ed) Social Change and Modernisation; Lessons from Eastern Europe. Berlin / Walter de Gruyter.

Kramer, M. (1995): Polish Workers and the Post-Communist Transition, 1989-1993. Communist and Post-Communist Studies. 28.1.pp.71-114.

Legge, K. (1995): Human Resource Management: Rhetorics and Realities. Basingstoke / MacMillan.

Lempkowski, B. (1992): Romantics: Pioneers of Capitalism in the Polish Economy of the 1980s. Scandinavian Management Journal. 8.3.pp259-263.

Lundy, O. / Cowling, A. (1996): Strategic Human Resource Management. London / Routledge.

Mabey, C. / Salaman, G. / Storey, J. (1998): HRM: A Strategic Introduction. Oxford / Blackwell.

Miszkala, A. (1996):Reakcje Spoleczne na Przemiany Ustrojowe. (Collective Reactions to Systemic Change). Lodz / Uniwersitet Lodzki.

Obloj, K. / Thomas, H. (1998): Transforming Former State-Owned Companies into Market Competitors in Poland: The ABB Experience. European Management Journal. 14.5. pp.467-476.

Ogbonna, E. (1996): Organisational Culture and Human Resource Management. in Blyton, P. / Turnbull, P. (eds) Re-assessing Human Resource Management. London / Sage.

Otta, W. (1996): Economic Transition and the Theory of the Firm. Journal of Transforming Economies and Societies. 3.1.pp.48-59.

Ouchi, W. (1981): Theory Z. Reading Mass /Addison-Wesley.

Pascale, T. / Athos, A. (1981): The Art of Japanese Management. London /Penguin.

Peiperl, M. / Estrin, S. (1998): Managerial Markets in Transition in Central and Eastern Europe: A Field Study and Implications . International Journal of Human Resource Management. 9.1. pp.58-78.

Peters, T. (1987): Thriving on Chaos. New York / Harper / Row.

Peters, T. / Waterman, R. (1982): In Search of Excellence: Lessons from America's Best Run Companies. New York / Harper / Row. 
Schaffer, R. / Thompson, M. (1992): Successful Change Programmes Begin with Results. Harvard Business Review. Jan/Feb.pp.80-89.

Schein, E. (1984): Coming to New Awareness of Organisational Culture. Sloan Management Review. 25. 2.

Schein, E. (1987): Organisational Culture. New York / Jossey Bass.

Soulsby, A. / Clark, E. (1995): Privatisation and the Restructuring of Enterprise Social and Welfare Assets in the Czech Republic. Industrial Relations Journal. 26.2 pp.97-110.

Staniszkas, J. (1979): On Some Contradictions of Socialist Society: The Case of Poland. Soviet Studies. 31. 2. pp.167-187.

Stark, D. (1992): Path Dependence and Privatisation Strategies in East Central Europe. East European Politics and Societies. 6.1. pp.17-54.

Thirkell, J./ Scase, R. / Vickerstaffe, S. (1995): Labour Relations and Political Change in Eastern Europe. London / UCL Press.

Williams, A. / Dobson, P. / Walters, M. (1993): Changing Culture. New Organisational Approaches. London / IPD.

Willmott, H. (1993): Strength is Ignorance: Slavery is Freedom; Managing Culture in Modern Organisations. Journal of Management Studies. 30.4. pp. 515-552.

Whitley, R. (1995): Transformation and Change in Europe: Critical Themes, in Dittrich, E. /Schmidt, G. / Whitley, R. (eds) Industrial Transformation in Europe. London / Sage. 